طول بيشرونده هسته جت سطحى در محيط يذيرنده كمعمق

\author{
رضا سجادى فر و جواد احديان'
}

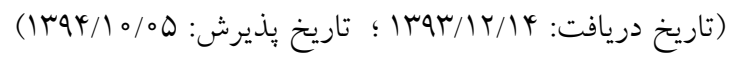

جكيده

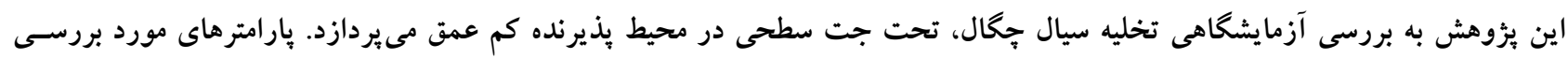

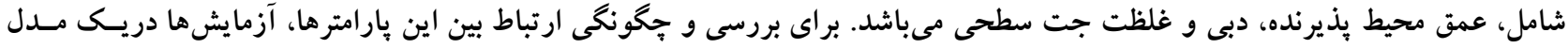

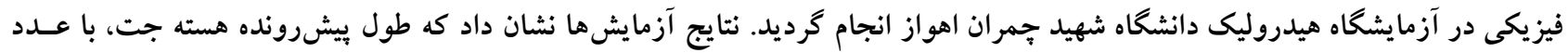

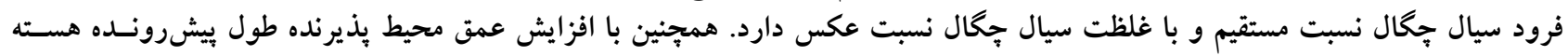

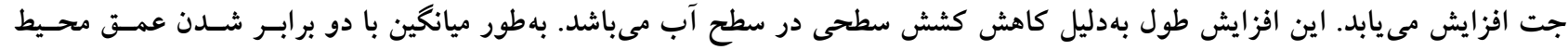

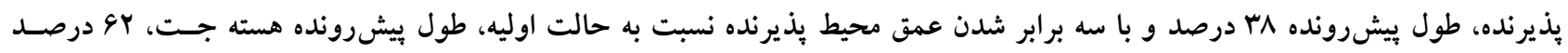

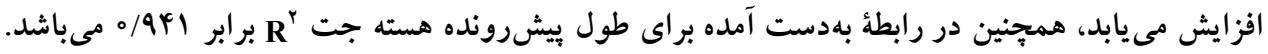

وازههاى كليدى: جت هيدروليكى، طول ييشرونده، محيط يذيرنده كمعمق

ا. كروه سازههاى آبى، دانشكده مهندسى علوم آب، دانشخاه شهيد جمر ان اهواز

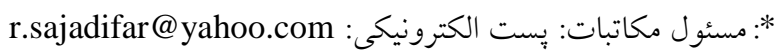


جريان، از شبيهسازى عددى بخخشيدگى با استفاده از يـى مــدل

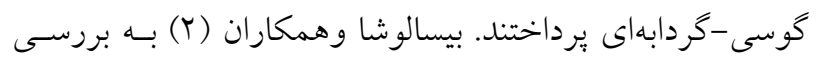

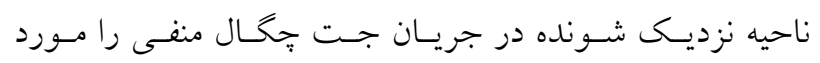

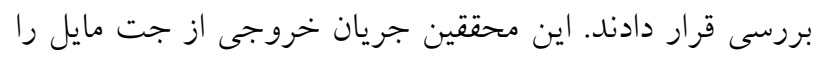

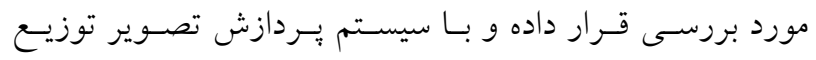
سرعت را در ناحيه نزديك جت بررسى نمودند. نتايج آنها نشان

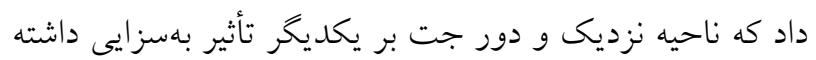

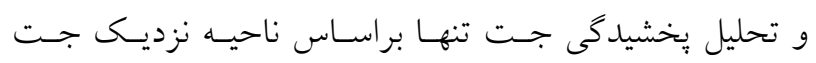

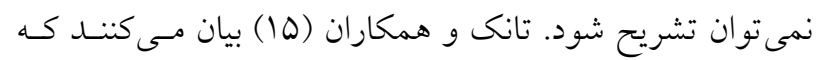

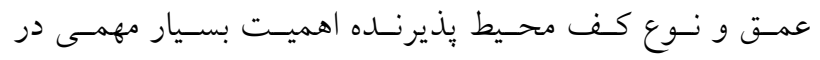

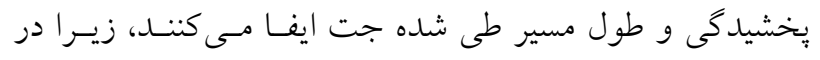

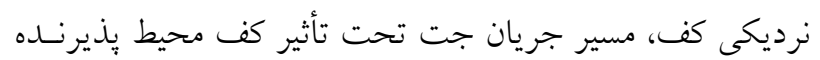

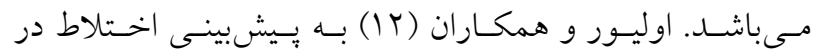
نزديكى ميدان تخليه آبشيرين كـنهـا در محسيطهـاى سـاكن

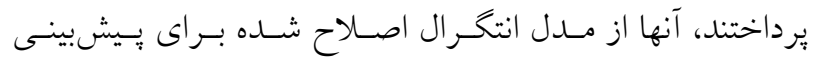

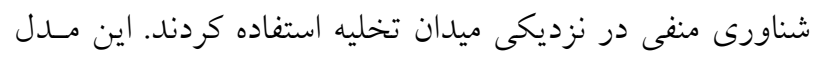

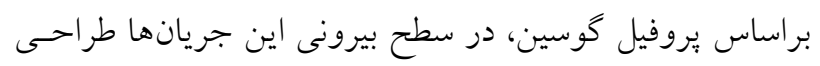

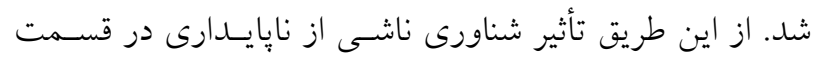

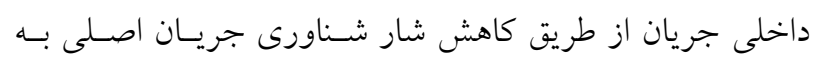

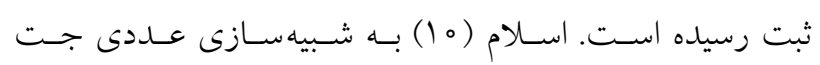

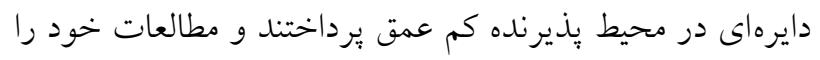

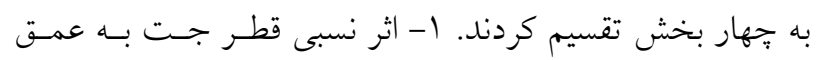

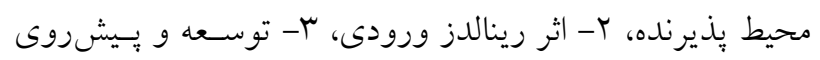

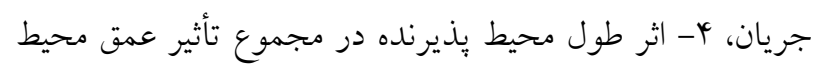

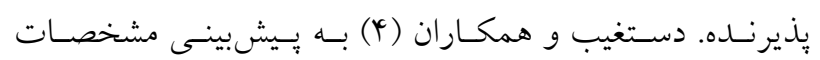

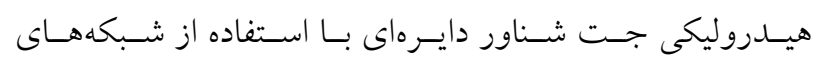

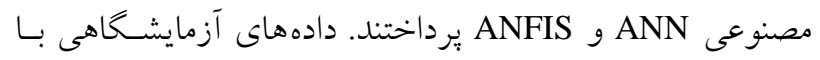
نتايج تحليلى ANN و ANFIS مقايسه كرديد. نتسايج نشـان داد كه شبكأ مصنوعى ANFIS نتايج بهترى نسـبت بـه ANN اريائس.

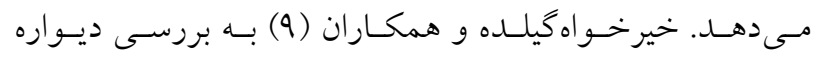

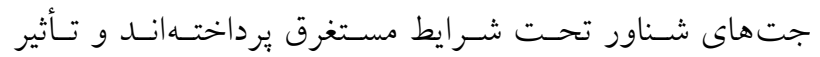

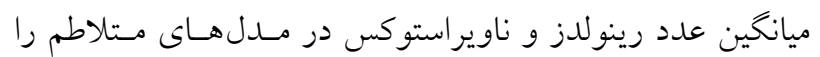

طيف گستردهاى از يُاب فر آيندهاى صنعتى، همانـــد ضـايعات كارخانها، سوختهاى محفظه احتراق در تيغهاى توربين وارد

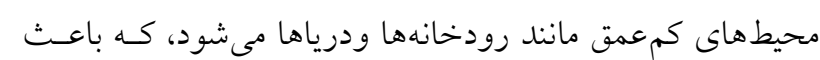

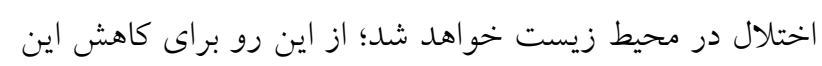

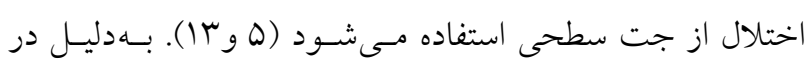

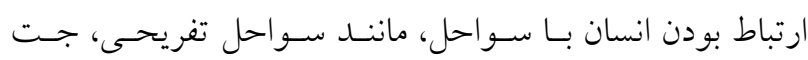
علاوه بر رقيقسازى جريان خروجى، سبب انتقال سـيال جِّـال

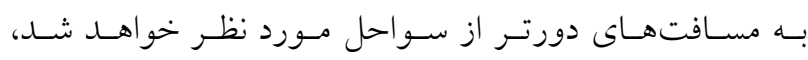

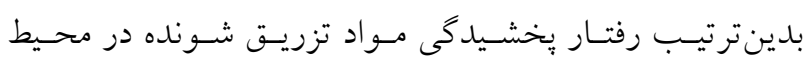

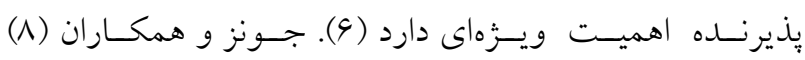

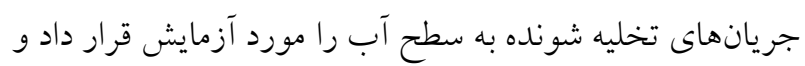

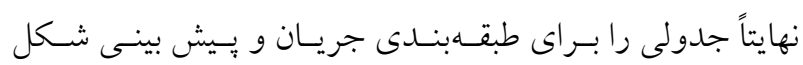

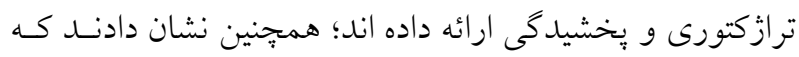

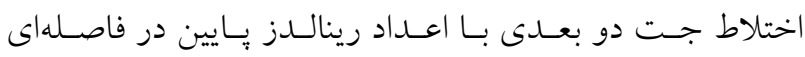

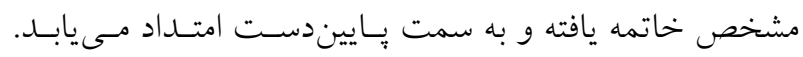
جيركا (V)، جت وروددى در آبهاى كم عمق را آنساليز كـرده و

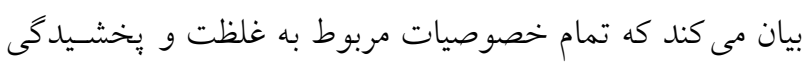

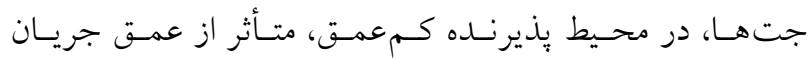

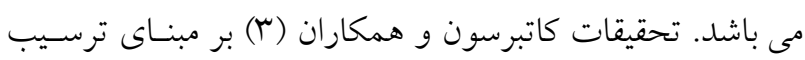

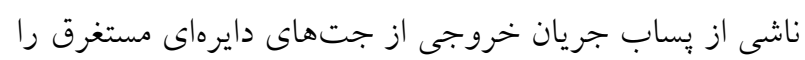

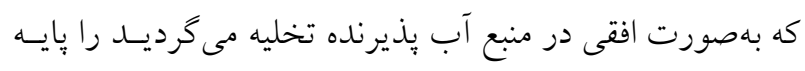

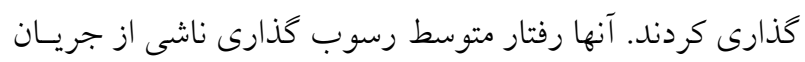

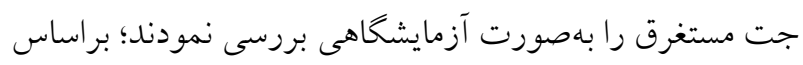

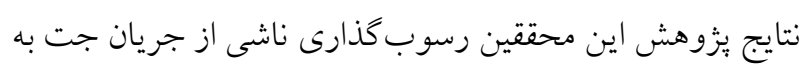

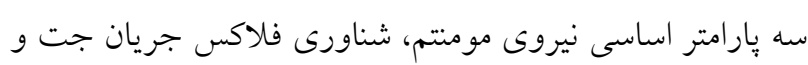

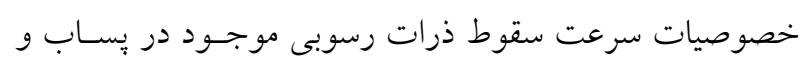

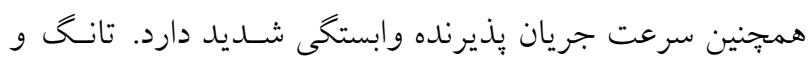

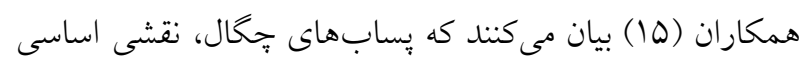

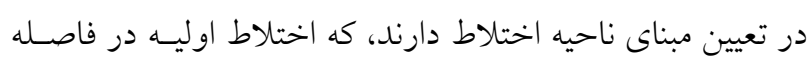
نزديك به خروجسى جـت و اخـتلاط ثانويسه در نـواحى دور از

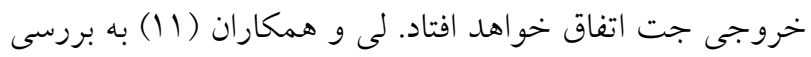



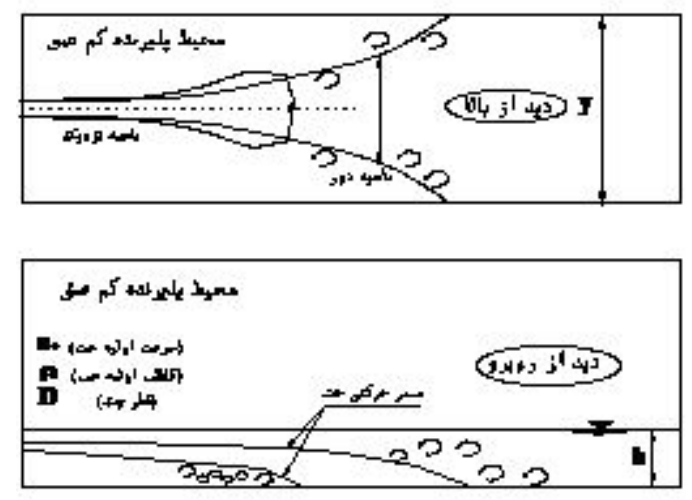

شكل 1. نمايش ترازكتورى جريان جت بههمراه بعضى پارامترها

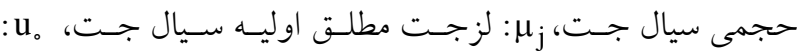
سرعت اوليه ورودى جت، D: قطر جت و در تمـام آزمـايشهـا اندازه آن ثابت و برابـر mm ا ا مسىباشـد، و و شـتاب ثقـل، C، غلظت اوليه سيال جت، H: عمق آب محسيط بذيرنــه، LL: طـول بيشرونده هسته جـت، و y: عـرض فلـوم مسىباشـــ براسـاس تحليل ابعادى بار امترهاى بدون بعد بهشرح زير مىباشند: $\mathrm{f}\left(\frac{\Delta \rho}{\rho_{\mathrm{a}}}, \frac{\rho_{\mathrm{j}} \mathrm{u}_{\circ} \mathrm{D}}{\mu_{\mathrm{j}}}, \frac{\mathrm{u}_{\circ}}{\sqrt{\mathrm{g}^{\prime} \mathrm{D}}}, \frac{\mathrm{H}}{\mathrm{D}}, \frac{\mathrm{L}}{\mathrm{D}}\right)=。$

در معادله (Y) پيارامرها بهترتيب از سـمت جِّبِ عبارتنـداز، دانسيته نسبى بين سيال جت و سـيال پذيرنسده، عـدد رينولـدز

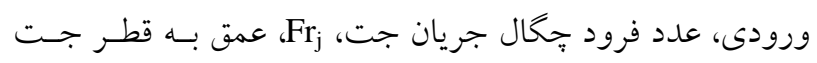

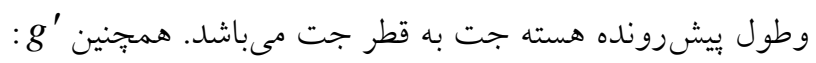

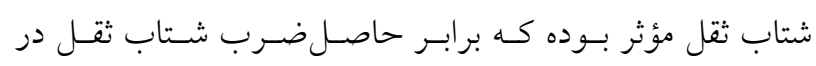

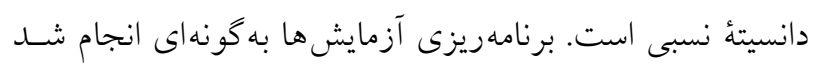
كه با توجه به شرايط واقعى جريـان تخليـه شـونده همـواره در

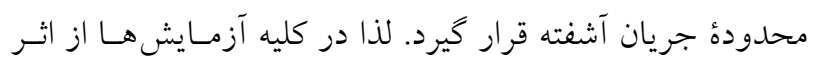
عدد رينو الدز صرفنظر شـــ. شـكل (1) برخهى از بارامترهـاى تعريف شده در اين يزووهش را به نشان مى دهد. شكل (1) مربوط به يهلان و مقطع جريان در محيط يذيرنــده مى باشد كه برخى از يارامترهاى حاكم در اين شكل نمايش داده شده است.
مورد بررسى قرار دادهاند. در مجموع تأثير عمق محيط يذيرنده، غلظت و دبى سـيال جخـال در نحــوه و نـوع يـر اكنش و طـول

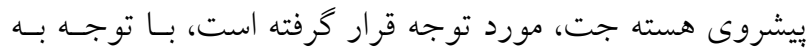
آنجهه كه در بخش مرورى بـر منـابع ذكر كرديــ، در يـزّوهش حاضر مقايسه آزمايشخاهى بخخشيدگى و طول بِيشرونده هسـته جت، در جريان جت سطحى در محيط كم عمق بهدليل اهميـت زياد و توجه كمتر محققين صورت يذيرفته است.

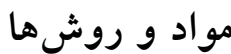

همان گونه كه اشاره شد، با توجه بـه هـدف مـورد نظـر در ايسن تحقيق اقدام به برنامهريزى آزمايشخاهى گرديد. بدينمنظور ابتدا

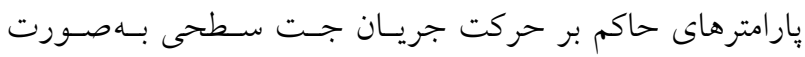
بلدون بعد ارائه مىشود.

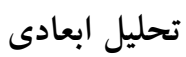
با توجه به محل قرار كرفتن جت، كه برروى سطح آب مىباشد، يار امترهاى حاكم بر بديده تخليه جريان جت سطحى، بـهمنظـور دستيابى به روابط بلدون بعد حاكم، اقدام به تحليـل ابعـادى بـين يار امترهاى مؤثر شده است. يارامترهاى مـؤثر در حركـت سـيال

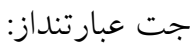

$f\left(\rho_{a}, \rho_{j}, \mu_{j}, u_{o}, D, g, C, H, y, L\right)=。$

در معادله (1)، 

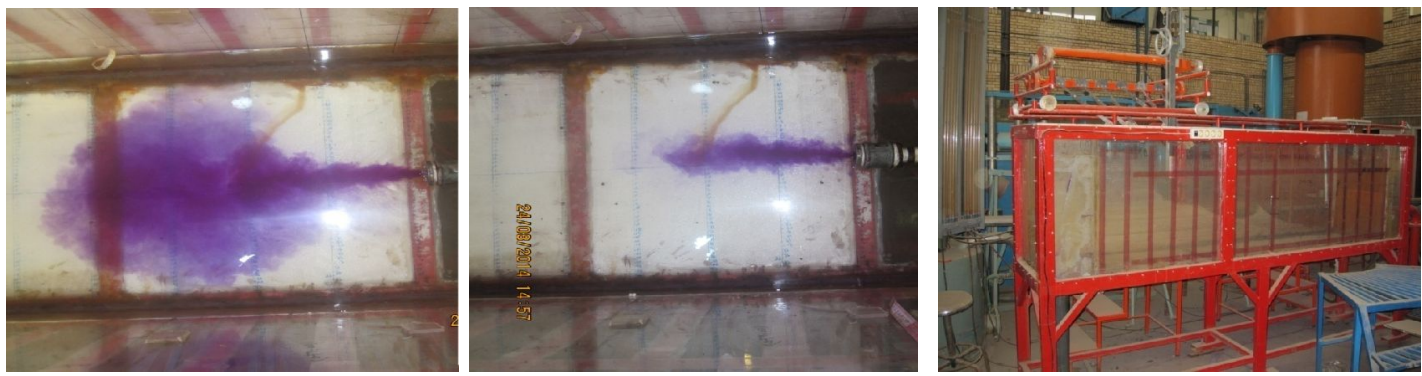

شكل r. فلوم آزمايشكاهى و نمونهاى از اجراى آزمايشها

بود، EC و دماى لحظهاى آب نمك مخـزن تزريـق و آب فلـوم

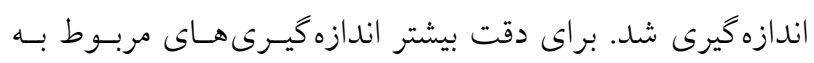

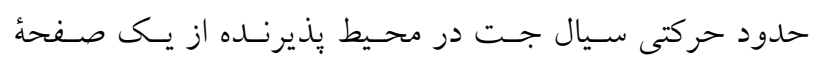

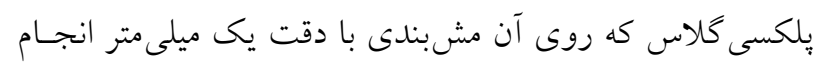

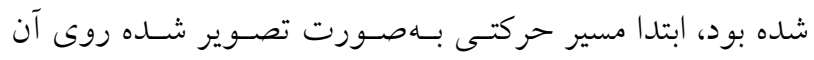

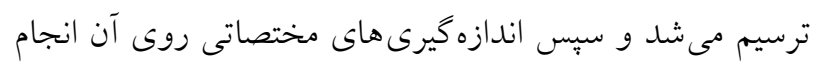

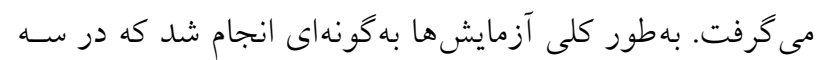
عمق محيط يذيرنده، سه غلظت و سه دبى جت انجام شد.

\section{نتايج و بحث} همان كونه كه در بخش تحليل ابعادى اشاره كرديد، اين مقاله بر

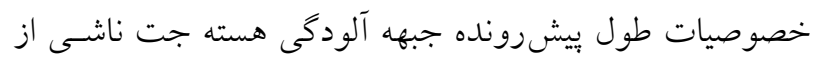
تزريق جت سطحى در محيط كم عمق پايه كذارى شـده اسـت. در اين قسمت به بحـث و بررسى بارامترهـاى مـؤثر بـر طـول

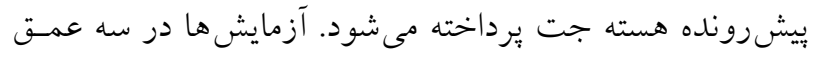

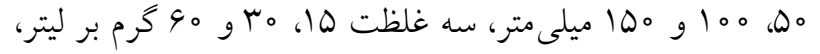

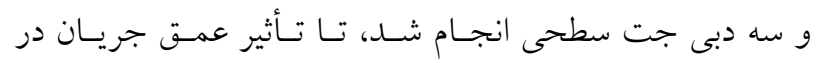
محيط يذيرنده و غلظت ودبى جت سطحى بر طول بيشرونـاه

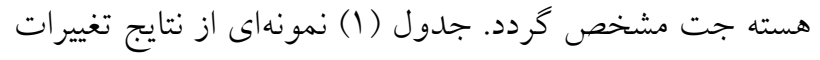

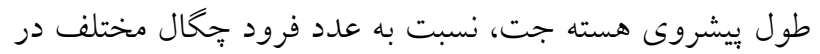

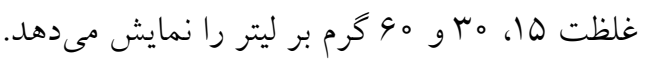

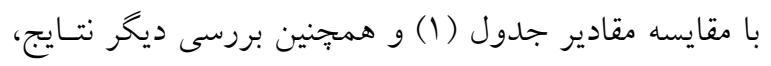

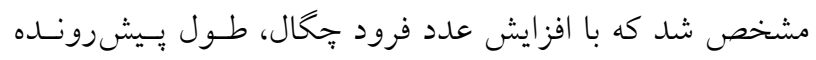

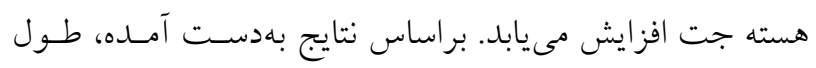
يّشرونده هسته جت از غلظتهاى كم به زياد كاهش مسى يابــ.
مدل آزمايشخاهى

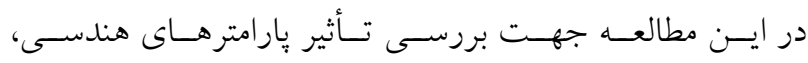

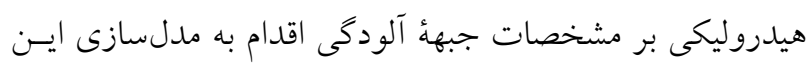

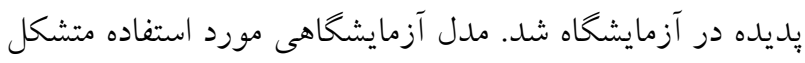

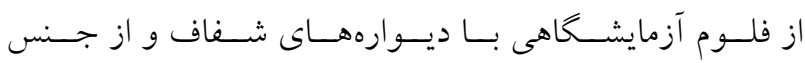

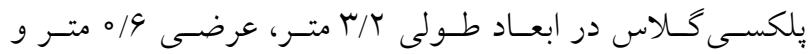

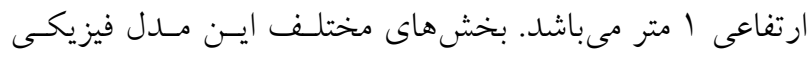

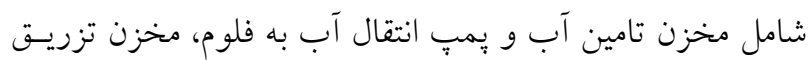
جت و يمبٍ اختلاط بهمنظور همخن نمودن سيال جت، فلـوم و

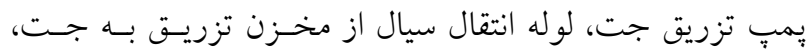

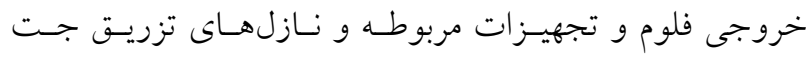

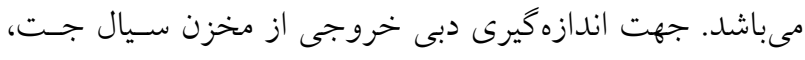

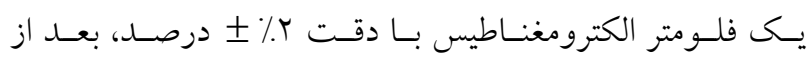

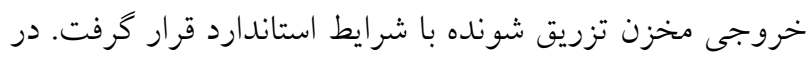

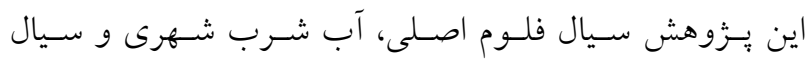

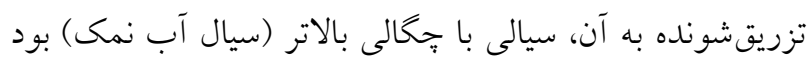

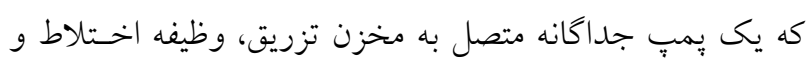

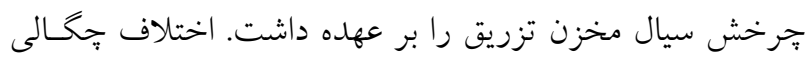

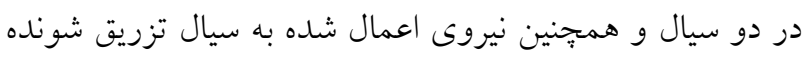

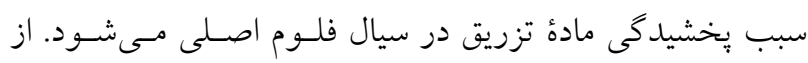

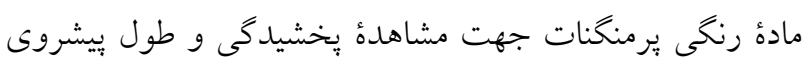

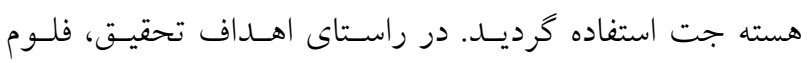
آزمايش ها امكان برداشت مختصات جريان خروجى جت رداد را دارا

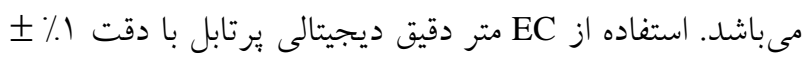

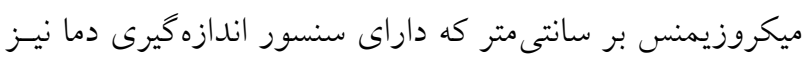




\begin{tabular}{|c|c|c|c|c|c|c|c|c|}
\hline \multicolumn{3}{|c|}{ غلظت ها گرم بر ليتر } & \multicolumn{3}{|c|}{ غلظت هب گرم بر } & \multicolumn{3}{|c|}{ غلظت هو گرم بر } \\
\hline $\mathrm{Fr}_{i}$ & $\mathrm{~L}$ & $\mathrm{H}$ & $\mathrm{Fr}_{i}$ & $\mathrm{~L}$ & $\mathrm{H}$ & $\mathrm{Fr}_{\mathrm{i}}$ & $\mathrm{L}$ & $\mathrm{H}$ \\
\hline 100 & $0 \circ 0$ & 100 & 100 & ס & 100 & 100 & TYO & 100 \\
\hline 100 & kro & 100 & 100 & rVo & 100 & 100 & IVo & 100 \\
\hline 100 & TVQ & Q. & 100 & rlo & ఎ० & 100 & Iro & ఎ. \\
\hline 99 & reo & 100 & 99 & rlo & 100 & 99 & $\mu_{0}$ & 100 \\
\hline 99 & TAD & 100 & 99 & $1 M$ & 100 & 99 & $1 r_{0}$ & 100 \\
\hline 99 & rVo & $\Delta \circ$ & 99 & 190 & Q. & 99 & 90 & Q. \\
\hline$\psi \wedge$ & YYO & 100 & $\uparrow \wedge$ & 10 & $10 \circ$ & $\varphi \wedge$ & 90 & 100 \\
\hline$\uparrow \wedge$ & rlo & 100 & $\uparrow \wedge$ & Ir & 100 & $\varphi \wedge$ & VQ & 100 \\
\hline$\uparrow \wedge$ & $1 \wedge 0$ & $\Delta_{0}$ & $\uparrow \wedge$ & $9 / 1$ & Q० & $\varphi \wedge$ & 90 & Q. \\
\hline
\end{tabular}

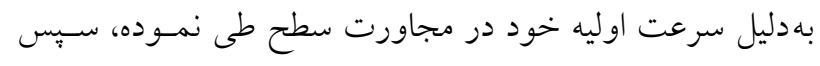

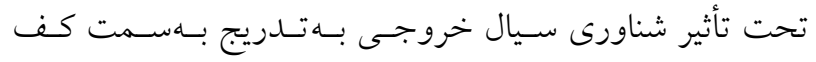
انحر اف مىيابل. يسابهاى سنخين خروجى از تخليه كنندهــاى

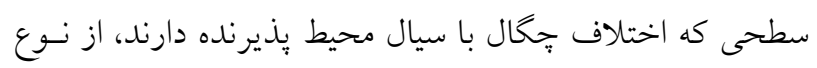

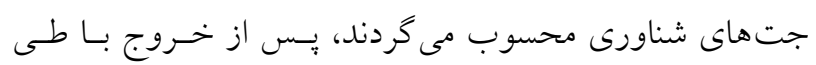
بخشى از مسير در مجاورت سطح، به تـدريج بيشـتر بـهسمت اعماق محيط منحرف شده و در نهايت با رسـيدن بـه بسـتر، در مجاورت آن آرامش مىيابد. در اين قسمت به بحث و بررسى و

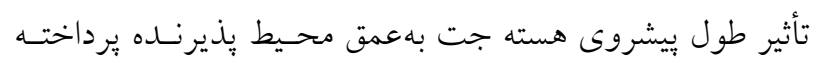

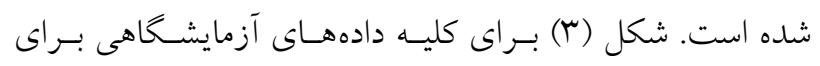
بررسى و تأثير طول بيشروى هسته جت به عمق محيط يذيرنده در غلظت مختلف نمايش مىدهد. همانطوركه در شكل (Y) مشاهده مىشود، با افـزايش عـدد فرود جّحال بهدليل افزايش سـرعت و مــومنتم ورودى اوليـهـ در يك طول ثابت، طول يِشرونده هسته جت افزايش مىيابــ. در يك غلظت و فرود ثابت با افزايش عمق، طول بيشرونده هسته جت افزايش مى يابد، دليل اين افزايش، كاهش كشـش سـطى آب، با افزايش عمق محيط بذيرنده مىباشد، همجنين با افزايش غلظت طول بيش رونده هسته جت بهدليل افزايش جّالى سـيال جت، كاهش مىيابد. در غلظت ها، هبو هو گرم بر ليتر بـا دو

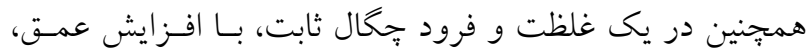

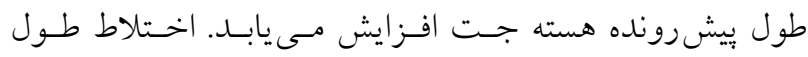
بيشرونده هسته جت با جريان بيرامون محيط بذيرنسـده حـداقل بوده، بنابراين سرعت هسته مركزى ثابت مىباشد. از اين ناحيـه به بعل، جريان بير امون بهتدريج بهدرون ناحيه حركتى جت نفوذ نمــوده و باعــث بيشــروى خــط مركـزى جــت مسى شـــود. بهعبارتديخر از اين ناحيه به بعد جريان بيرامون با جريان جت بركي

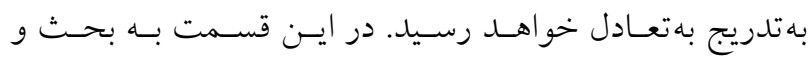
بررسى و تاثير اعداد بى بعد بر طول بيشروى هسته جت يرداخته

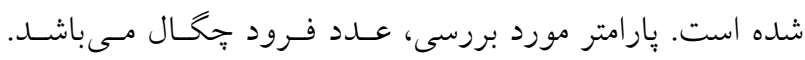
شكل (T) براى كليه دادهاى آزمايشخاهى تغييرات بدون بعد را نسبت به عدد فرود جّخال در اعماق مختلف نمايش مىدهد. همانطور كه در شكل (r) مشاهده مىشود، با افـزايش عـدد فرود جِحال بهدليل افزايش سـرعت و مــومنتم ورودى اوليـهـ در يك طول ثابت، طول يِيشرونده هسته جــت افـزايش مسىيابـد. همجنين با افزايش غلظت جت، طول يـيش رونسـده هسـته جـت بهدليل جخال بودن سيال كاهش مى يابد. جريان سـطحى تخليـه شونده بهعلت اختلاف جخالى با سيال محيط، الخوى متفاوتى از حركت جريان در محيط تحت عنوان رزيم جـت شـناور ايجـاد خواهد نمود. در اين حالت، جريان بخشى از مسـير بذيرنسده را 


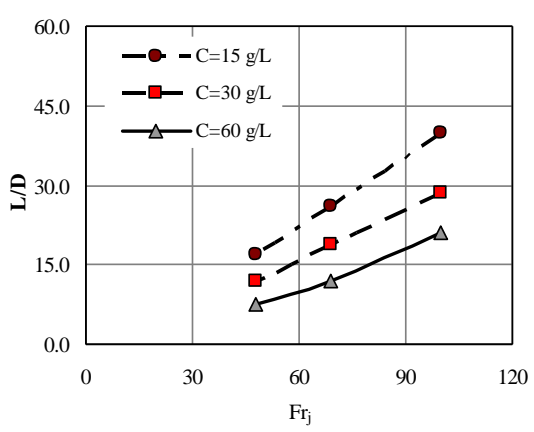

(ب)

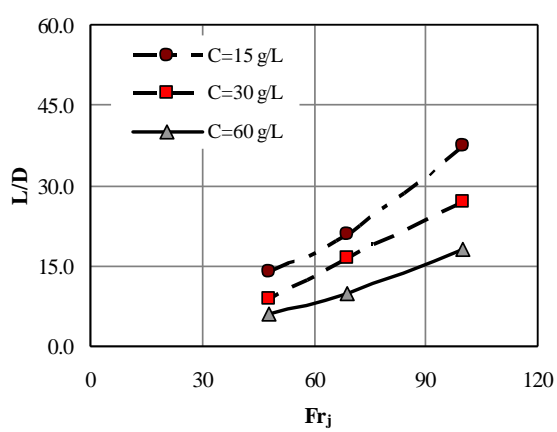

(الف)

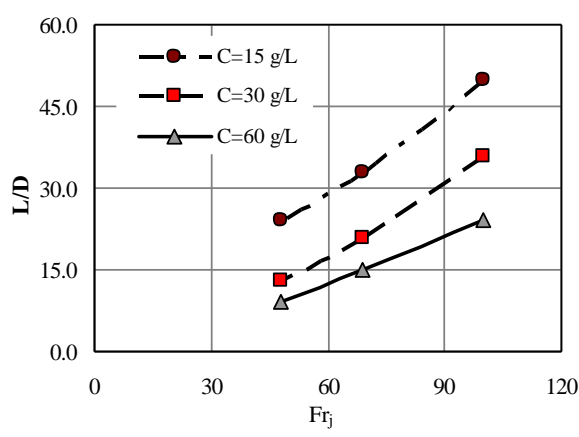

(ج)

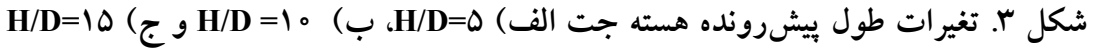
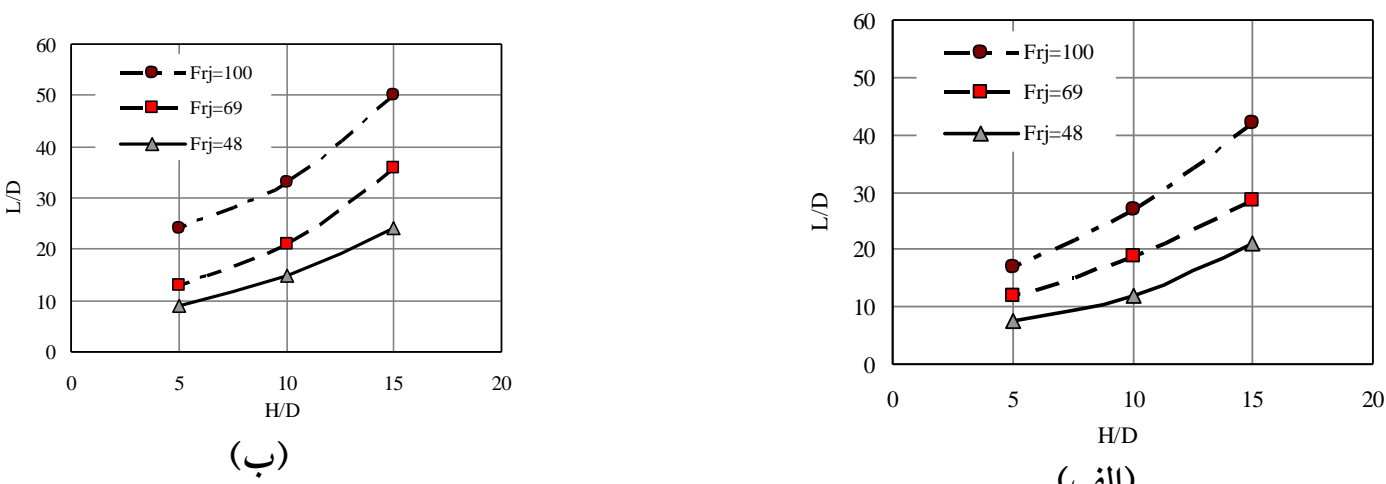

(الف)

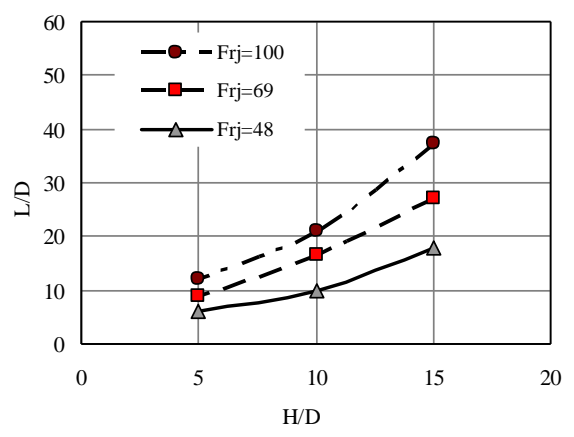

(ج)

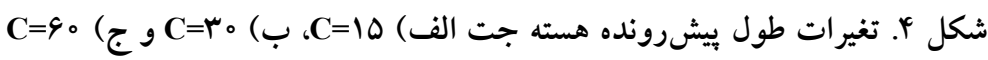


(10) در سال 1997 در بررسى جت هاى خروجسى، نقش شـار

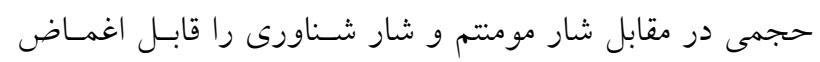

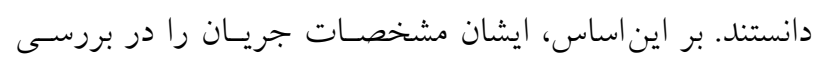

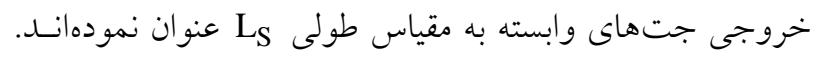

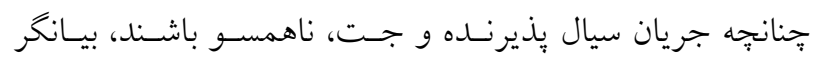

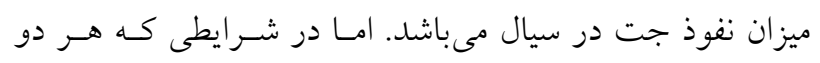

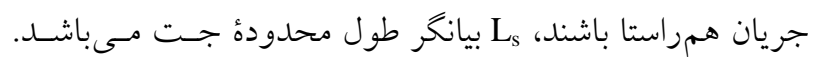

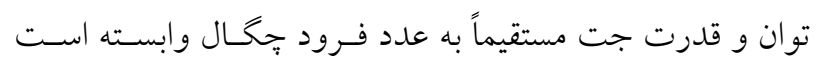

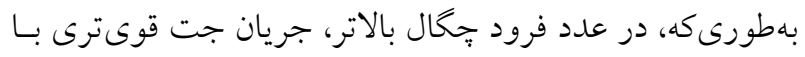
مومتتم اوليه بيشتر، توليد مىشود. با توجه به اين كه قطر جت در برد

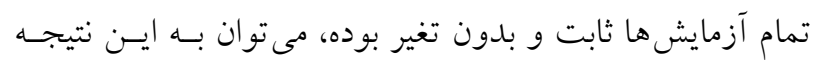
رسيد كه نسبت مقياس طولى بهعدد فرود بستخى دارد. كه ناحيه

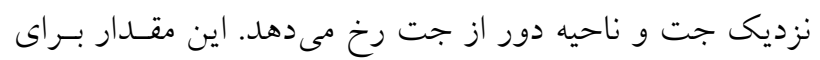

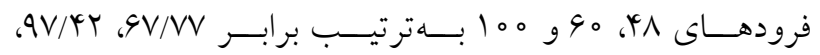

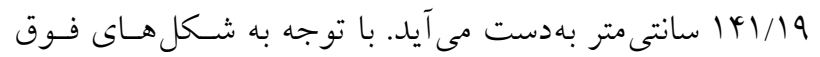

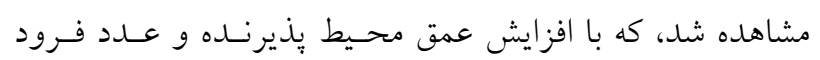

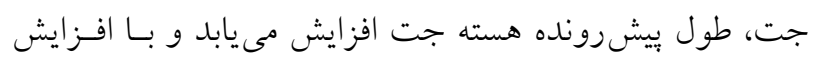

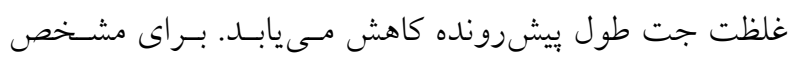

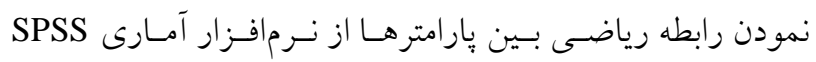

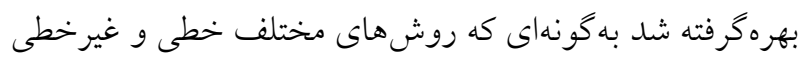

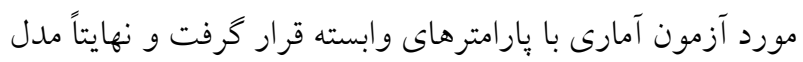

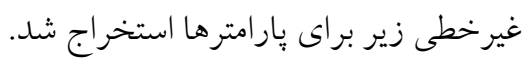
$\frac{\mathrm{L}}{\mathrm{D}}=1 / 991 \mathrm{Fr}_{\mathrm{j}}^{1 / 9 \wedge \varphi}-90 / / 49\left(\frac{\mathrm{H}}{\mathrm{D}}\right)^{-0 / 101}+1 \wedge r / 1 \wedge(\ln \mathrm{C})^{-1 / 4 \% r}$ در نهايت رابطةُ (9) بهعنوان بهترين رابطه معرفى شد، زيراعلاوه

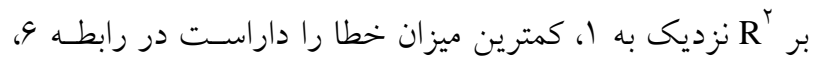

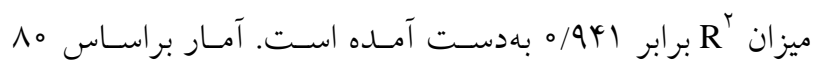

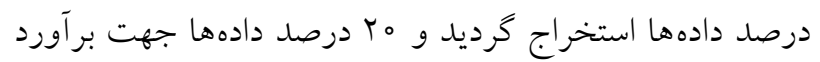

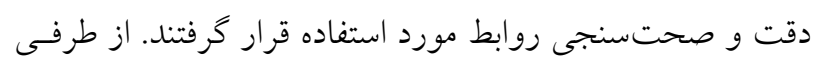

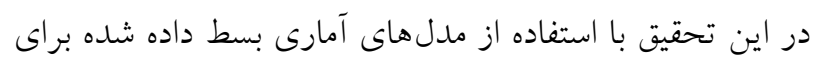

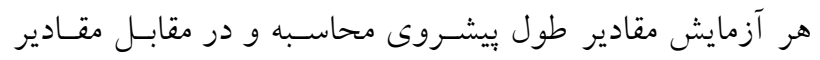

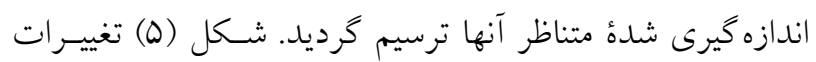
مقادير اندازهيرى شده طول بيشروى در مقابل مقادير
برابر شدن عمق محيط بِذيرنده، طول بيشرونده هسته جت،

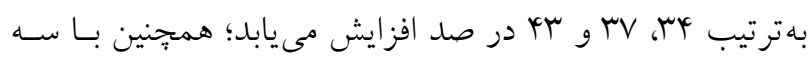

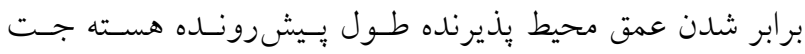

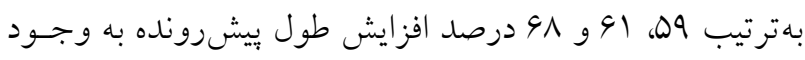
آمده است؛ بهطور ميانخين با دو برابر شدن عمق محيط يذ بذيرنده،

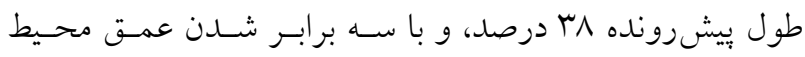

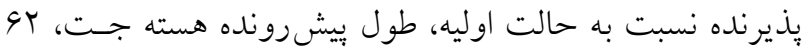

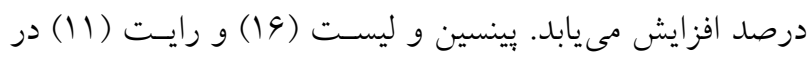

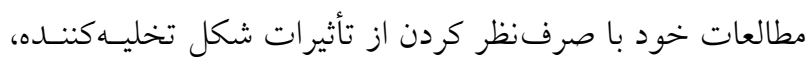
متغيرهاى بالا را قالب دو مقيـاس طـولى تخليـه، Lاس و مقيـاس

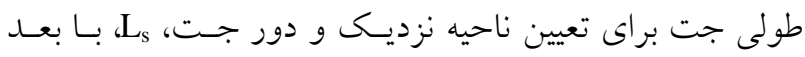

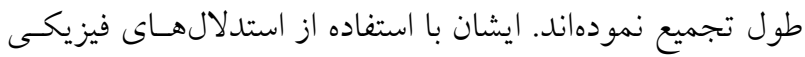

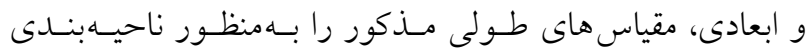

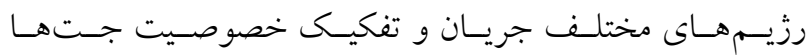
بلمورت زير ييشنهاد نمودند:

$\mathrm{L}_{\mathrm{Q}}=\frac{\mathrm{Q}}{\mathrm{M}^{\circ / \Delta}}$

$\mathrm{L}_{\mathrm{s}}=\frac{\mathrm{M}^{\mathrm{o} / \mathrm{v}}}{\mathrm{F}_{\mathrm{o}}^{\circ / \Delta}}$

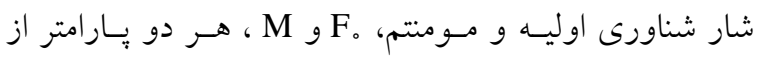
خصوصيات جريان تخليه شونده مىباشند. از آنجايى كه مقـدار

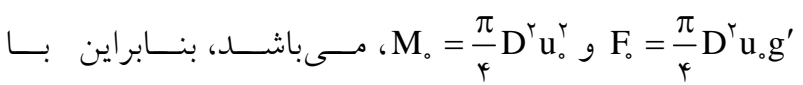
جايخذارى در رابطهى (Y) مقياس طولى با فرمول ساده زير بيـان

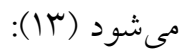
$\mathrm{L}_{\mathrm{s}}=\left(\frac{\pi}{\mathrm{r}}\right)^{\circ / / \diamond} \mathrm{D} \cdot \mathrm{Fr}_{\mathrm{j}}$

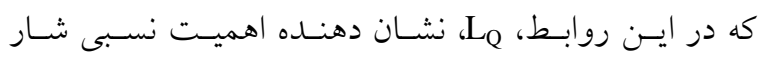
حجمى به شار مومنتم جريان جت خروجى است. ايسن بـارامتر

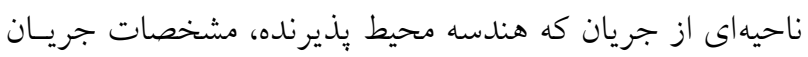

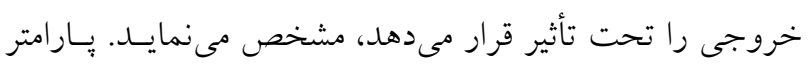

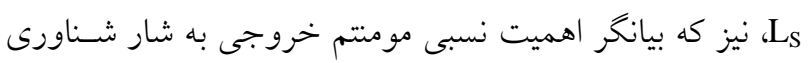

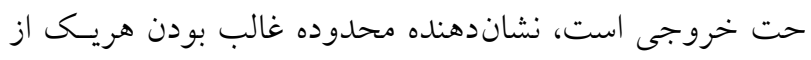
شارهاى مذكور در جريان خروجسى اسـت. رابرتسز و همكـاران 


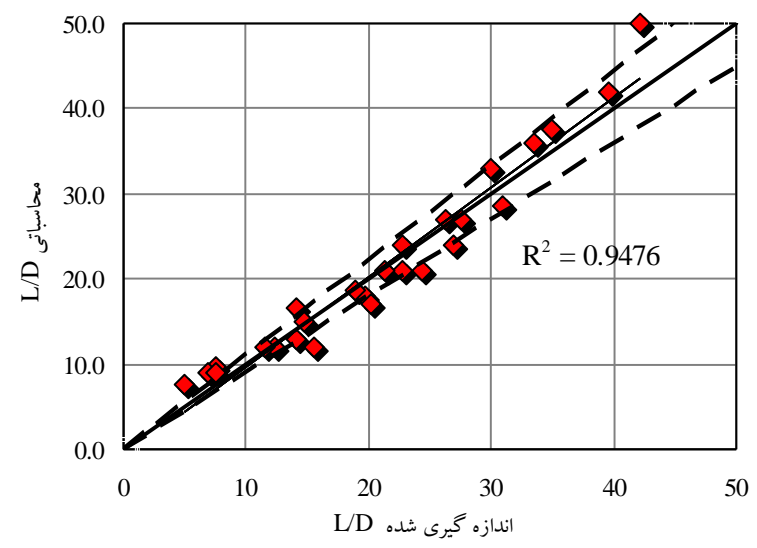

شكل ه. تغييرات مقادير محاسباتى در مقابل مقادير اندازهگيرى

محاسبه طول بيش رونده هسته جت، در محيط بذيرنده متحـرك

$$
\text { محاسبه كردد. }
$$$$
\text { تتيجه كيرى }
$$

از مجمـوع توضـيحات منــرج در بنــهاى قبـل كـه حاصـل مطالعات و نتايج آزمايشخاهى يزوهش حاضر مىباشد بهصورت

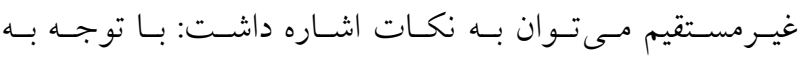

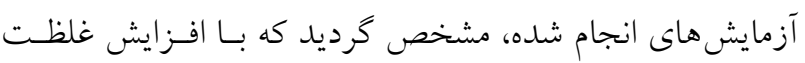
سيال جت، طول بيش رونــده هسـته جـت كـاهش مسىيابــ. بـا افزايش عدد فرود، نيروى مومنتم افزايش مىيابد، بههمين دليـل با افزايش عدد فرود جّخال، طول بيشرونده هسته جت افزايش

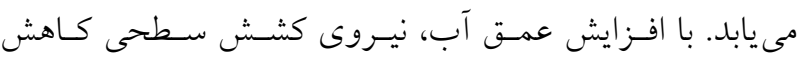
مى يابد، بههمين دليل بــا افـزايش عمـق محسيط بذّيرنــده طـول ييشرونده هسته جت افزايش مى يابد.
محاسباتى آن با استفاده از رابطهُ (9) را نمايش مىدهد. شكل (ه) براساس م T درصد دادههاى اندازهذيـرى شـده و محاسباتى كه در استخراج رابطهُ (9) نقشى نداشتهاند، اسـتخراج كرديده است. ضريب ركرسيون نيز در ايسن حالـت نمايسهاى از ميزان دقّت هر يك از مدلهاى آمارى خواهد بود. مقدار ضريب

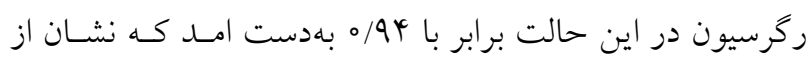

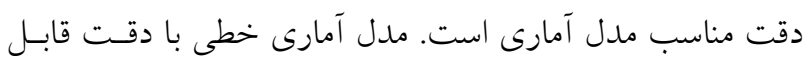
قبولى قادر به بِيشبينى يارامترهاى مهم در حركت جت سطحى جُخال بوده و همانطورى كه مشاهده مسى شـود، اكثـر دادههـاى محاسباتى در مقابل مقادير بيشبينى بر روى خط هاب درجه واقع

$$
\text { بيشنهادات }
$$

محاسبه طول بيش رونده هسته جت، در جـت هــاى مسـتغرق و آزاد محاسبه كردد.

\section{منابع مورد استفاده}

1. Barata J. M. M. 1996. Fountain flows produced by multiple impinging jets in a cross flow. J. AIAA 34(12): 25232530.

2. Besalduch, L. A., M. G. Badas, S. Ferrari and G. Querzoli. 2014. On the near field behavior of inclined negatively buoyant jets. EPJ Conferences, Vol. 67, University of Cagliari, DICAAR (Dipartimanto di Ingegneria Civil, Ambientalee Architectural). Cagliari. Italy.

3. Cuthberston Alan J. S., A. Peter and P. A. Davis. 2008. Deposition from particle-laden. round, turbulent, horizontal buoyant jets in stationary and following receiving fluids. J. of Hydraulic Engineering. ASCE. 134(4): 390-402.

4. Dastgheib, S., S. H. Musavi-Jahromi and A. Nowroozpour. 2013. Predicting hydraulic properties of circular buoyant 
jets in the static ambient flow using ANN and ANFIS. World Environmental and Water Resources Congress 2013. pp. 1880-1895.

5. Fric, T. F., A. Roshko. 1994. Vertical structure in the wake of a transverse jet. J. of Fluid Mechanics ASCE 279: 147.

6. Fischer, H. B. 1981. Mixing in inland and coastal waters. Academic Press. California.

7. Jirka, H. G. 1999. Life study of plane jet bounded in shallow water layer. J. of Hydraulic Engineering, ASCE. 125(8): 817-826.

8. Jones, G., J. Nash, R. Doneker and G. Jirka. 2007. Buoyant surface discharges into water bodies. I: Flow classification and prediction methodology. J. of Hydraulic Engineering. ASCE 133(9): 1010-1020.

9. Kheirkhah Gildeh, H., A. Mohammadian, I. Nistor and H. Qiblawey. 2014. Numerical modeling of turbulent buoyant wall jets in stationary ambient water. J. of Hydraulic Engineering. ASCE 140(6): 04014012.

10. Islam, M. R., D. Z. Zhu. 2011. Flow upstream of two-dimensional intakes. J. of Hydraulic Engineering, ASCE 137(1): 129-134.

11. Lee, J. and I. W. Seo. 2000. Numerical simulation of adverted thermal using gaussian-vortex model. J. of Engineering Mechanics. ASCE 126(10): 1098-1106.

12. Oliver, C. J., M. J. Davidson and R. I. Nokes. 2012. Predicting the near-field mixing of desalination discharges in a station environment. J. of Desalination 309: 148-155

13. Roberts P. J. W., A. Ferrierer and G. Daviero. 1997. Mixing in inclined jet. J. of Hydraulic Engineering. ASCE 123(8): 693-699.

14. Wright, S. J. 1977. Effects of ambient cross flow and density at ratification on the characteristic behavior of round turbulent buoyant jets, Report No. KH-R-36, W.M KECK Lab. of Hydraulic. and Water resort. California Inset.

15. Tang, H., J. Paik, F. Sotiropoulos and T. Khangaonkar. 2008. Three-Dimensional numerical modeling of initial mixing of thermal discharges at real-life configurations. J. of Hydraulic Engineering. ASCE 134(9): 1210-1224.

16. Pincince, A. B. and E.J. List. 1973. Disposal of brine into an estuary. J. of Water Pollution Control Federation 45(11): 2335-2344. 


\title{
Progressive Length of the Surface Jet Core in Shallow Acceptor Ambient
}

\author{
R. Sajadi Far* and J. Ahadiyan ${ }^{1}$
}

(Received: March 05-2015 ; Accepted : Dec. 26-2015)

\begin{abstract}
In this research dense fluid discharge was experimentally investigated under the surface jet in the shallow acceptor. The investigated parameters were depth of the acceptor ambient, flow rate and the concentration of surface jet. In order to investigate the relationship between these parameters, a-physical model experiments were performed in the hydraulic laboratory of Shahid Chamran University. The results showed that progressive length of the surface jet core is directly proportional to Froude number of fluid density, and is inversly proportional to fluid density concentration. Besides, the progressive length of the jet core increases with increasing the depth of the acceptor ambient. This length increase is due to the decrease of water surface tension. In average, increasing the depth of acceptor ambient twice, the progressive length will increase $38 \%$, and its increasing three times, will increase progressive length of jet core $62 \%$. Besides, in the relationship obtained for the progressive length of jet core $\mathrm{R}^{2}$ is 0.94 .
\end{abstract}

Keywords: Surface jet, Jet core progressive, Shallow acceptor.

1. Dept. of Hydraulic Structures, Faculty of Water Sci Eng., Shahid Chamran University of Ahvaz, Ahvaz, Iran.

*: Corresponding Author, Email: r.sajadifar@yahoo.com 